\title{
Enhanced recovery after surgery for hip fractures: a systematic review and meta- analysis
}

\author{
Song-yang Liu(D, Ci Li and Pei-xun Zhang*
}

\begin{abstract}
Background: Enhanced recovery after surgery (ERAS) programs have achieved promising results in many surgical specialties. However, uncertainty still remains regarding the effect of ERAS on hip fractures. The objective of this review was to investigate the clinical prognosis of ERAS programs in terms of (1) hospital-related endpoints (time to surgery [TTS], length of stay [LOS]), (2) readmission rate, (3) complications, and (4) mortality.

Methods: Published literature was searched in the PubMed, EMBASE, and Cochrane Library databases. All of the included studies met the inclusion criteria. The primary outcomes were TTS and LOS. The secondary outcomes included the 30-day readmission rate, overall complication rate, specific complication rate (delirium and urinary tract infection), and 30-day and 1-year mortality. Language was restricted to English. The data analysis was carried out by Review Manager 5.3.

Results: A total of 7 published studies (9869 patients) were finally included, and these were all cohort studies. The meta-analysis showed that the TTS, LOS, and overall complication rate were significantly reduced in the ERAS group compared with the control group $(p<0.01)$. Moreover, no significant change was found in the 30-day readmission rate or 30-day and 1-year mortality.

Conclusions: ERAS significantly decreases the TTS, LOS, and complication rate without increasing readmission rate and mortality, which adds to the evidence that the implementation of ERAS is beneficial to patients undergoing hip fracture repair surgeries.
\end{abstract}

Keywords: ERAS, Hip fracture, Time to surgery, LOS, Complication rate

\section{Background}

As one of the most common injuries in the elderly, hip fracture is predicted to reach 7.3-21.3 million cases around the world by 2050 (Leigheb et al. 2013). Several studies have reported 30-day mortality rates ranging from 6.1 to $8.7 \%$ (Bretherton and Parker 2015; Pincus et al. 2017; Sheikh et al. 2017) and 1-year mortality rates ranging from 21 to 30\% (Klop et al. 2014; Lund et al. 2014; Mundi et al. 2014). Given the predicted increasing

\footnotetext{
* Correspondence: zhangpeixun@bjmu.edu.cn

Department of Orthopedics and Trauma, Peking University People's Hospital, Beijing, China
}

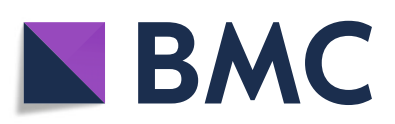

(c) The Author(s). 2021 Open Access This article is licensed under a Creative Commons Attribution 4.0 International License, which permits use, sharing, adaptation, distribution and reproduction in any medium or format, as long as you give appropriate credit to the original author(s) and the source, provide a link to the Creative Commons licence, and indicate if changes were made. The images or other third party material in this article are included in the article's Creative Commons licence, unless indicated otherwise in a credit line to the material. If material is not included in the article's Creative Commons licence and your intended use is not permitted by statutory regulation or exceeds the permitted use, you will need to obtain permission directly from the copyright holder. To view a copy of this licence, visit http://creativecommons.org/licenses/by/4.0/. The Creative Commons Public Domain Dedication waiver (http://creativecommons.org/publicdomain/zero/1.0/) applies to the data made available in this article, unless otherwise stated in a credit line to the data. nificant public health concern.

Beside the progress of surgical techniques, some new perioperative care approaches have been developed to improve the outcome and reduce mortality after hip fractures. One example of such an approach is the Enhanced recovery after surgery ERAS program. ERAS was initially advocated in the 1990s by H. Kehlet (1997). ERAS programs address preoperative, intraoperative, and postoperative intervention during the recovery from surgery. The core elements of ERAS include preoperative nutritional support, effective analgesia, optimal pain 
control, fluid management, postoperative early mobilization and so on (Ljungqvist et al. 2017). The promotion of ERAS has achieved satisfactory results, including a reduction in mortality, length of stay (LOS), and complication rates in many surgical specialties (Bozic et al. 2010; Chen $\mathrm{Hu}$ et al. 2012; Larsen et al. 2008). However, its effect and application in hip fracture surgery have not yet been proven.

Hereby, we performed a systematic review and metaanalysis to investigate the clinical prognosis of ERAS programs in terms of (1) hospital-related endpoints (time to surgery [TTS], LOS), (2) readmission rate, (3) complications, and (4) mortality.

\section{Methods}

\section{Search strategy and criteria}

The systematic review of related literature was performed according to Preferred Reporting Items for Systematic Review and Meta-analysis (PRISMA) guidelines (Moher et al. 2009). Two researchers independently searched the PubMed, EMBASE and Cochrane Library databases from January 1966 to July 2020. The language was restricted to English. The search strategy used was as follows: (ERAS or enhanced recovery or fast track) and (hip fractures or femoral fractures or intertrochanteric fractures or subtrochanteric fractures). Reference lists of related papers were also manually searched.

We included studies that implemented ERAS programs in patients undergoing hip fracture surgery. Although the details of ERAS were not unified among these studies, only the studies covering pre-, intra-, and postoperative management of the surgery (Ljungqvist et al. 2017) were included. The exclusion criteria included case reports, editorials, commentaries and reviews.

\section{Study selection and data extraction}

Two authors (Liu and Li) screened the titles and abstracts independently and eliminated duplicates. Both authors reviewed the full texts of the potentially eligible studies and determined the final articles included. Discrepancies were settled by discussion between the two authors. The quality of eligible studies was assessed using the modified Newcastle-Ottawa scale (Stang 2010).

Two review authors extracted the relevant information, including the publication authors, publication years, sample size, age, sex, fracture grade, and follow-up duration. Any inconsistency was either resolved by a third investigator or negotiated between the two original authors.

\section{Outcome measures}

The primary outcomes were time to surgery (TTS) and length of stay (LOS). The secondary outcomes included 30-day readmission rates, 30-day mortality and 1-year mortality, overall complication rate, and specific complication rate (delirium, urinary tract infection, and surgical site infection). Time to surgery was defined as the waiting time from admission to surgery.

\section{Statistical analysis}

Meta-analysis was completed by Review Manager (RevMan, version 5.3). For continuous outcomes (LOS and TTS), the mean difference (MD) with 95\% confidence interval (CI) was calculated, while for dichotomous data (the 30-day mortality, readmission, overall and specific complication rate), the odds ratio (OR) was calculated. Statistical heterogeneity was assessed by $I^{2}$ measurement as follows: $I^{2}<50 \%$ : low; $50-75 \%$ : moderate; and $>75 \%$ high (Higgins et al. 2003). When $I^{2}<50 \%$, no significant heterogeneity was indicated, and a random effects model was applied. Otherwise, a fixed effects model was used, and a sensitivity analysis was performed. A $P$ value funnel plot was generated to evaluate the publication bias (Fig. 1).

\section{Results}

\section{Search results and study characteristics}

The initial literature search generated 173 citations. After removing duplicates, 139 articles underwent title and abstract screening, and 127 were excluded. Following this step, 12 articles were read as full text, and 7 of them (Gomez et al. 2019; Haugan et al. 2017; Kang et al. 2019; Liu et al. 2017; Macfie et al. 2012; Pedersen et al. 2008; Pollmann et al. 2019), involving 9869 participants, met the inclusion criteria and were finally included. All of the included studies were cohort studies. The distributions of age, sex, and types of fracture were similar among the studies. The perioperative fast-track or enhanced recovery processes were all clearly described and were shown in Table 2 . The quality of the included studies was evaluated based on the Newcastle-Ottawa Scale (NOS) and was shown in Fig. 2. Only 2 studies in which the confounders were adjusted for during analysis received 9 stars. The remainder achieved 7 stars, as the comparability of cohorts accounted for the majority of bias. The search process is shown in Fig. 1. The basic characteristics of the 7 studies are outlined in Table 1.

\section{Time to surgery}

There were 6 studies (Gomez et al. 2019; Haugan et al. 2017; Liu et al. 2017; Macfie et al. 2012; Pedersen 2008; Pollmann et al. 2019) with available TTS data (Fig. 3). A random effects model was applied, as the heterogeneity was significant $\left(P<0.00001, I^{2}=86 \%\right)$. A significant reduction in the mean TTS was found for the ERAS patients compared with the control group ( $\mathrm{MD}=-2.96$, 95\% CI: $-5.40-0.53, P=0.02$ ). 


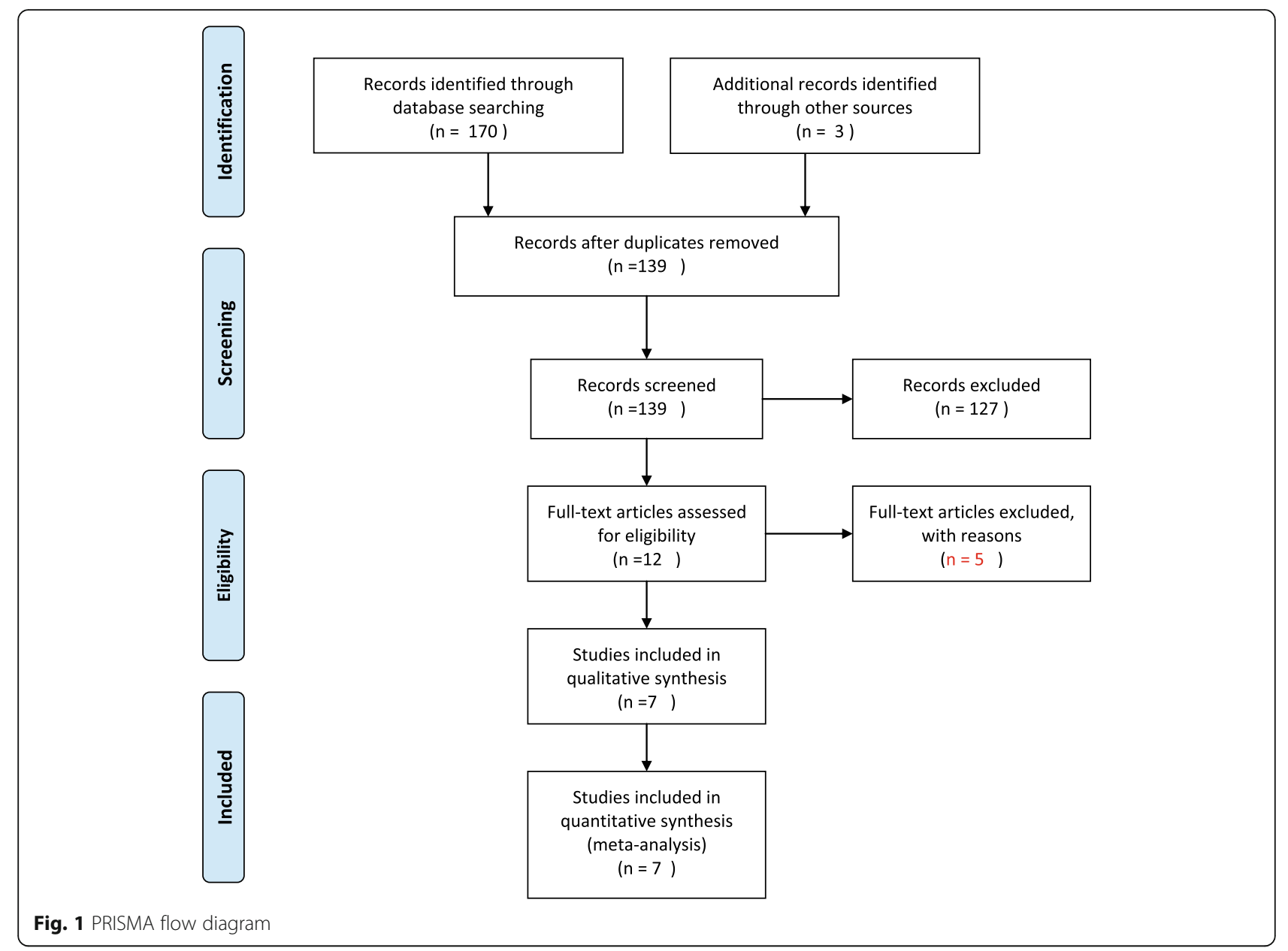

\section{Length of stay}

There were 6 studies (Gomez et al. 2019; Haugan et al. 2017; Kang et al. 2019; Liu et al. 2017; Pedersen 2008; Pollmann et al. 2019) with available length of stay (LOS) data (Fig. 4). A random effects model was applied $(P<$ $\left.0.00001, I^{2}=90 \%\right)$. A significant reduction in the mean LOS was found for the ERAS patients compared with the control group $(\mathrm{MD}=-2.64,95 \% \mathrm{CI}:-3.63-1.65, P$ $<0.00001)$.

\section{Thirty-day readmission}

There were 4 studies (Haugan et al. 2017; Kang et al. 2019; Liu et al. 2017; Pollmann et al. 2019) with available overall complication rate data (Fig. 5). A fixed effects model was applied $\left(P=0.24, I^{2}=29 \%\right)$. No increase in the 30-day readmission rate was found for the ERAS group $(\mathrm{OR}=1.09,95 \% \mathrm{CI}: 0.97-1.24, P=0.16)$ compared with the control group.

\section{Thirty-day mortality}

There were 3 studies (Haugan et al. 2017; Macfie et al. 2012; Pollmann et al. 2019) with available 30-day mortality data (Fig. 6). A fixed effects model was applied ( $P$ $\left.=0.57, I^{2}=0\right)$. No significant reduction in 30-day mortality was found for the ERAS group (OR $=0.84,95 \%$ CI: $0.67-1.06, P=0.14$ ) compared with the control group.

\section{One-year mortality}

There were 4 studies (Gomez et al. 2019; Haugan et al. 2017; Pedersen 2008; Pollmann et al. 2019) with available 1-year mortality data (Fig. 7). A fixed effects model was applied $\left(P=0.35, I^{2}=10 \%\right)$. No significant reduction in 1-year mortality was found for the ERAS group (OR $=0.99$, 95\% CI: $0.87-1.14, P=0.92$ ) compared with the control group.

\section{Overall complication rate}

There were 4 studies (Kang et al. 2019; Liu et al. 2017; Macfie et al. 2012; Pedersen 2008) with available overall complication rate data (Fig. 8). A fixed effects model was applied $\left(P=0.22, I^{2}=32 \%\right)$. A significant reduction in the overall complication rate was found for the ERAS group $(\mathrm{MD}=0.68,95 \% \mathrm{CI}: 0.57-0.80, P<0.00001)$ compared with the control group. 


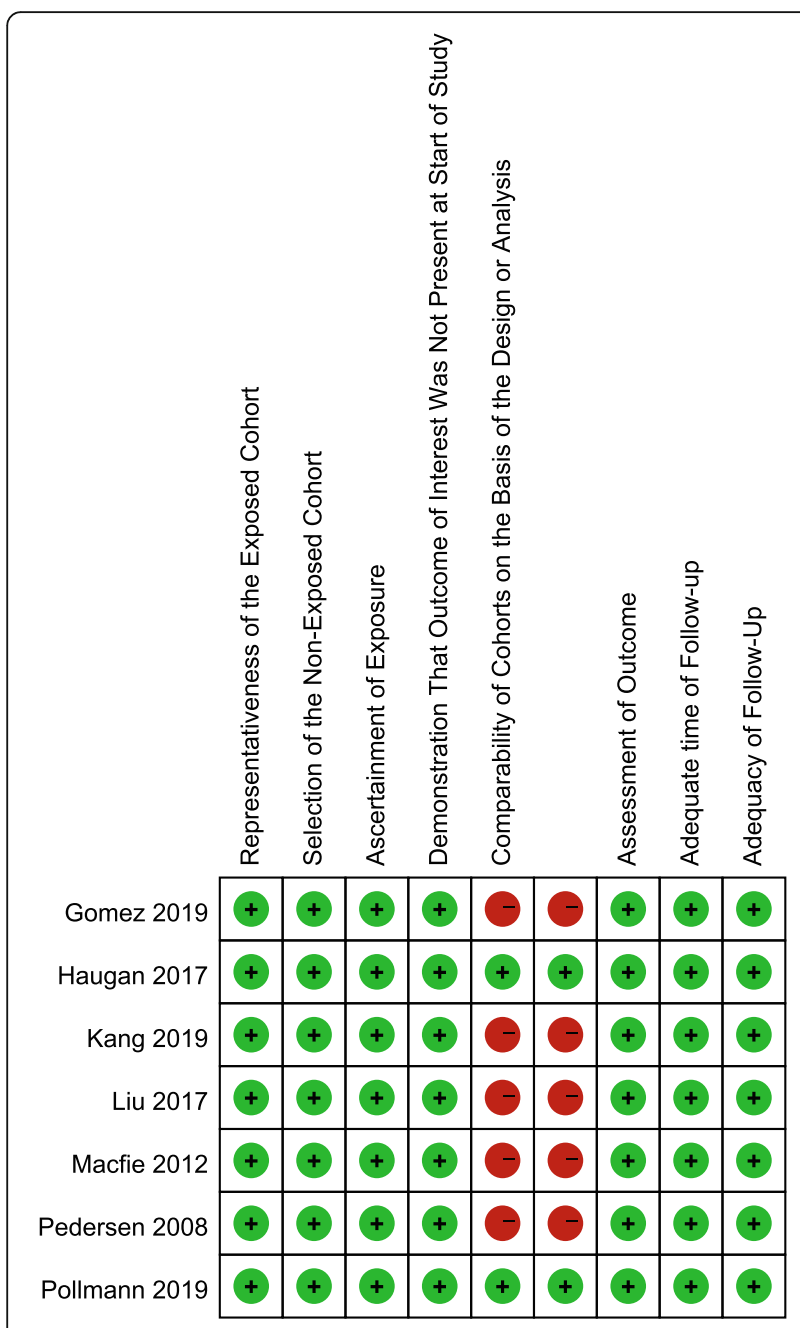

Fig. 2 NOS assessment of bias in cohort studies. + low risk of bias, high risk of bias

\section{Delirium rate}

There were 3 studies (Gomez et al. 2019; Kang et al. 2019; Pedersen 2008) with available delirium rate data (Fig. 9). A random effects model was applied $(P=$ $\left.0.07, I^{2}=63 \%\right)$. A significant reduction in the delirium rate was found for the ERAS group $(\mathrm{OR}=0.46$, 95\% CI: $0.23-0.93, P<0.03)$ compared with the control group.

\section{Urinary tract infection rate}

There were 3 studies (Gomez et al. 2019; Kang et al. 2019; Pedersen 2008) with available urinary tract infection (UTI) rate data (Fig. 10). A fixed effects model was applied $\left(P=0.59, I^{2}=0\right)$. A significant reduction was found for the ERAS group (OR $=0.39,95 \%$ CI: $0.21-$ $0.71, P=0.002)$ compared with the control group.

\section{Publication bias}

A funnel plot was used with TTS as an indicator. The 6 studies were distributed asymmetrically in the plot, which suggested a high impact of publication bias on the results (Fig. 11).

\section{Discussion}

This is the first meta-analysis to investigate the effects of the ERAS protocol among hip fracture patients. The primary outcome measures, including LOS and TTS, were significantly reduced in patients treated with the ERAS program. Of equal importance, the overall complication rate, delirium rate, and UTI rate were also significantly reduced, while the 30-day readmission rate and mortality (30 days and 1 year) were not increased compared to those of the control groups. Our results were consistent with previous meta-analytical findings in other surgical specialties, such as hepatectomy (Ni et al. 2015),

Table 1 Basic characteristics of the included studies

\begin{tabular}{|c|c|c|c|c|c|c|c|c|}
\hline Studies & Years & Country, Center & $\begin{array}{l}\text { Number(E/ } \\
\text { C) }\end{array}$ & $\begin{array}{l}\text { Mean } \\
\operatorname{age}(E / C)\end{array}$ & $\begin{array}{l}\text { Male/ } \\
\text { Female }\end{array}$ & $\begin{array}{l}\text { Follow-up } \\
\text { duration }\end{array}$ & Type of fracture & $\begin{array}{l}\text { Study } \\
\text { design }\end{array}$ \\
\hline $\begin{array}{l}\text { Pollmann (Pollmann et al. } \\
\text { 2019) }\end{array}$ & 2019 & $\begin{array}{l}\text { Single-center, } \\
\text { Norway }\end{array}$ & $1140 / 1090$ & 79.6/79.7 & $701 / 1529$ & 1 year & $\begin{array}{l}\text { Proximal femur } \\
\text { fracture }\end{array}$ & $\begin{array}{l}\text { Cohort } \\
\text { study }\end{array}$ \\
\hline Kang (Kang et al. 2019) & 2019 & $\begin{array}{l}\text { Single-center, } \\
\text { China }\end{array}$ & $50 / 50$ & $77.81 / 78.32$ & $31 / 69$ & $30 \mathrm{~d}$ & $\begin{array}{l}\text { Intertrochanteric } \\
\text { fracture }\end{array}$ & $\begin{array}{l}\text { Cohort } \\
\text { study }\end{array}$ \\
\hline $\begin{array}{l}\text { Gomez (Gomez et al. } \\
\text { 2019) }\end{array}$ & 2019 & $\begin{array}{l}\text { Single-center, } \\
\text { France }\end{array}$ & $27 / 27$ & $84.5 / 85.0$ & $14 / 40$ & 1 year & $\begin{array}{l}\text { Peritrochanteric } \\
\text { fracture }\end{array}$ & $\begin{array}{l}\text { Cohort } \\
\text { study }\end{array}$ \\
\hline $\begin{array}{l}\text { Haugan (Haugan et al. } \\
\text { 2017) }\end{array}$ & 2017 & $\begin{array}{l}\text { Single center, } \\
\text { Norway }\end{array}$ & 1032/788 & $83.1 / 83.1$ & $512 / 1308$ & 1 year & Hip fracture & $\begin{array}{l}\text { Cohort } \\
\text { study }\end{array}$ \\
\hline Liu (Liu et al. 2017) & 2017 & Multicenter, USA & $2514 / 2488$ & $79.7 / 79.3$ & $1586 / 3416$ & $30 \mathrm{~d}$ & Hip fracture & $\begin{array}{l}\text { Cohort } \\
\text { study }\end{array}$ \\
\hline $\begin{array}{l}\text { Macfie (Macfie et al. } \\
\text { 2012) }\end{array}$ & 2012 & $\begin{array}{l}\text { Single-center, } \\
\text { Denmark }\end{array}$ & $117 / 115$ & $82.5 / 82.7$ & $52 / 180$ & 6 months & $\begin{array}{l}\text { Proximal femoral } \\
\text { fractures }\end{array}$ & $\begin{array}{l}\text { Cohort } \\
\text { study }\end{array}$ \\
\hline Pedersen (Pedersen 2008) & 2008 & England & $178 / 357$ & / & $127 / 408$ & 1 year & Hip fracture & $\begin{array}{l}\text { Cohort } \\
\text { study }\end{array}$ \\
\hline
\end{tabular}




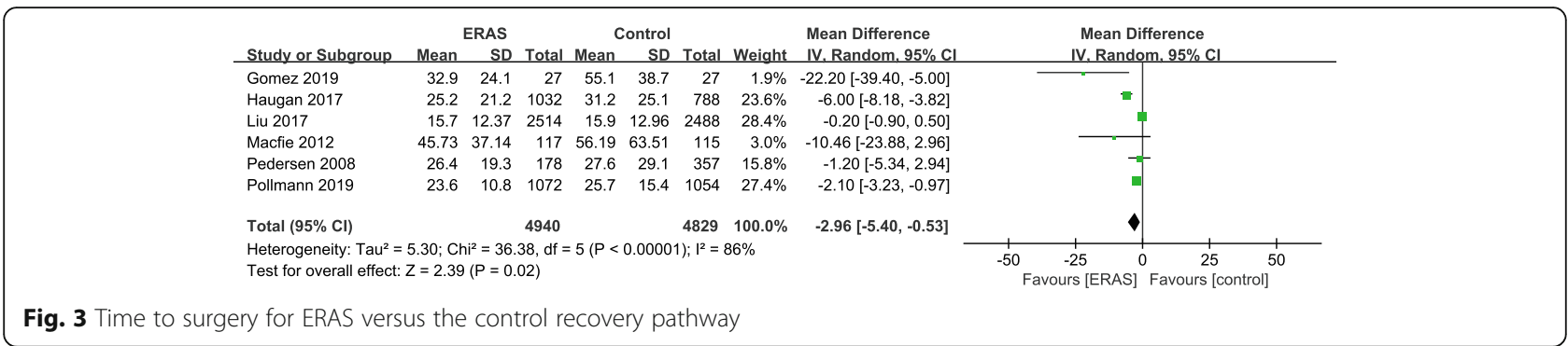

colorectal surgery (Greco et al. 2014), and pancreatic surgery (Coolsen et al. 2013).

In Table 2, we summarize the various ERAS protocols performed in each study. Despite the diversity of ERAS protocols during pre-, intra-, and postoperative stages, some core elements were shared in common. The most commonly emphasized elements include nutrition therapy (protein drinks), opiate-sparing pain relief, avoidance of drains, oxygen therapy, and early mobilization. These details might serve as a reference for future guidelines of standard ERAS programs in hip fracture surgery.

\section{Time to surgery}

Current guidelines suggest that surgery be completed within $48 \mathrm{~h}$ of hip fracture (Brox et al. 2015), as many clinical trials reported that a longer time to surgery was associated with a longer hospital stay (Al-Ani et al. 2008), higher mortality (Nyholm et al. 2015), increased risk of infection (Westberg et al. 2013), and other complications (Petersen et al. 2006). A high-quality metaanalysis also showed that earlier surgery and shortened time to surgery after hip fracture were associated with a lower risk of death and lower rates of postoperative complications among hip fracture patients (Simunovic et al. 2010). In our review, we found that the mean time to surgery was reduced by $2.96 \mathrm{~h}$ in ERAS patients compared with the control group, which might exert a positive effect on the postoperative and complication rates.

\section{Length of stay}

The average LOS after hip fracture ranges widely from 5.6 to 45 days among different countries
(Ireland et al. 2015; Nikkel et al. 2015; Nordstrom et al. 2015; Sund et al. 2011). It was reported that prolonged LOS was related to an increased rate of healthcare-associated infections and some postoperative complications, such as delirium (Mosk et al. 2017). In addition, Nikkel et al. found that decreased LOS was related to reduced rates of early mortality (Nikkel et al. 2015). Furthermore, reduction of LOS is a reliable way to save tremendous amounts of hospital resources and costs (Kaoutzanis et al. 2018). Thus, numerous methods and ongoing efforts have been made to reduce the LOS.

ERAS has been demonstrated to be an effective way of reducing LOS. The current review showed that the mean reduction in LOS in ERAS patients was 2.64 days (95\% CI:) compared to that in controls, which was not only statistically significant but also clinically meaningful. The data are consistent with the findings in several other surgical specialties. Zhu et al. conducted a meta-analysis to evaluate the effects of ERAS on hip and knee arthroplasty and found that LOS was significantly lower in the ERAS group than in the control group (SMD $=-0.85$, 95\% CI: -1.24 to $-0.45, P=0.01$ ) without an increase in the 30-day readmission rate (Zhu et al. 2017). The results of a meta-analysis of noncolorectal abdominal surgery indicated a significant reduction (2.5 days) in the mean LOS for ERAS patients compared with the control group (Visioni et al. 2018). In addition, the reduction of time to surgery, optimized nutrition and fluid management, sufficient pain control, and early mobilization in the ERAS protocol comprehensively explain the reduced LOS in our review.

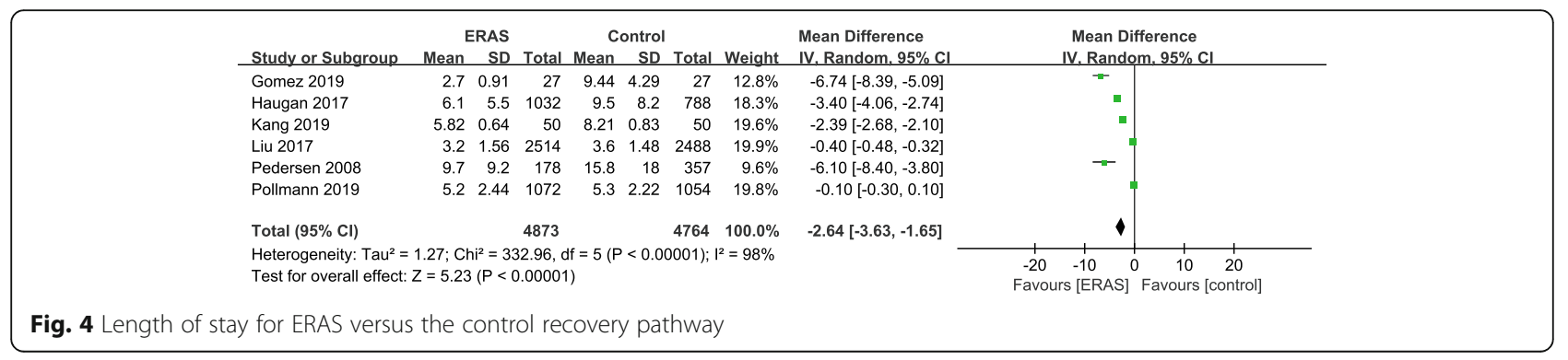




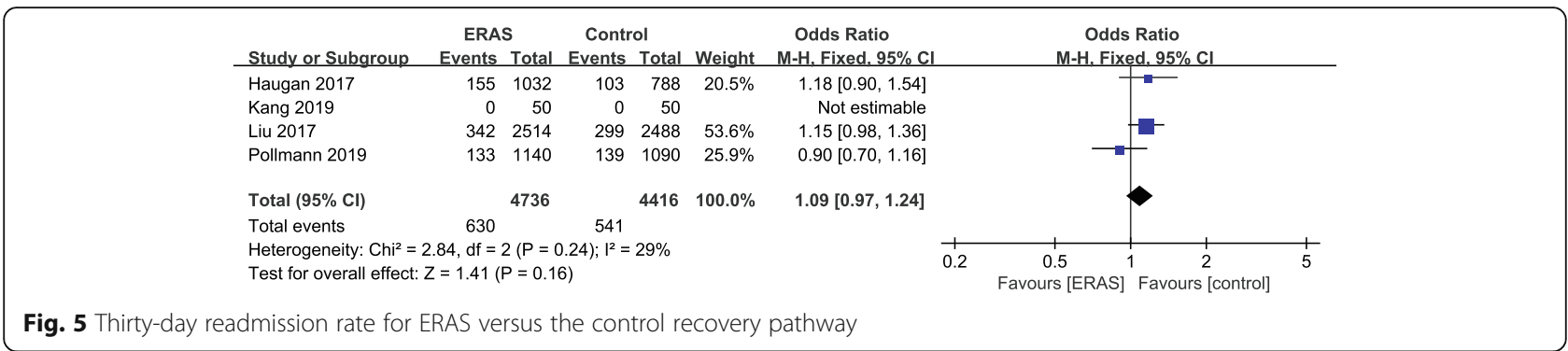

\section{Thirty-day readmission rate}

Thirty-day readmission is another important indicator used to evaluate the quality of surgery. Early readmission after hip fracture is associated with increased mortality and worse postoperative outcomes (French et al. 2008; Kates et al. 2015a, 2015b). Furthermore, a high readmission rate imposes a heavy financial burden on the healthcare system (Jencks et al. 2009; Kates et al. 2015a, 2015b). Therefore, growing attention has been drawn to investigating the risk of readmission and reducing the 30-day readmission rate after hip fracture surgery.

As mobilization and rehabilitation after discharge are of equal importance to hip fracture patients, some researchers are concerned that a shortened LOS is associated with an increased 30-day readmission rate (Capelastegui et al. 2008). The overall readmission rate in our review was $13.3 \%$, which is similar to the readmission rate $(10 \%)$ of a large-scale trial including 8434 hip fracture patients (Basques et al. 2015). It should be pointed out that the reduction in LOS was not at the expense of an increased readmission rate in our review $(\mathrm{OR}=1.09,95 \% \mathrm{CI}: 0.97-1.24, P=0.16)$. This result was consistent with several previous articles. A metaanalysis by Zhu et al. showed no significant difference in the 30-day readmission rate $(P=0.18)$ between ERAS and control groups among patients undergoing low extremity arthroplasty (Zhu et al. 2017). Visioni et al. (2018) reported no significant increase in the readmission rate in noncolorectal abdominal surgery. Khan MA reported that the most common causes of readmission after hip fracture were pneumonia, dehydration and renal dysfunction, and deteriorating mobility (Khan et al. 2012). More precise ERAS protocols to minimize these pre- and postoperative risk factors need to be panned and implemented.

\section{Overall complication rate}

The pain, bleeding, immobility, active inflammation, hypercoagulable status, and stress states resulting from hip fractures always precipitate various complications (Beloosesky et al. 2007; Chuang et al. 2005; Desborough 2000). The common complications of hip fractures include delirium, urinary tract infection (UTI), pneumonia, VTE, and surgical site infection (Investigators 2020).

Several studies have demonstrated that ERAS can decrease the overall complication rate (Varadhan et al. 2010; Zhu et al. 2017). Consistent with their findings, our findings revealed a significant reduction in the overall complication rate in the ERAS group $(\mathrm{OR}=0.68$, 95\% CI: $0.57-0.80, P<0.00001)$ compared with the control group. Due to the lack of data, we only chose delirium and UTI for specific complication analysis. The results show that the UTI and delirium were significantly reduced in our review. A recent large-scale randomized controlled trial (RCT) (Investigators 2020) indicated that surgery within $6 \mathrm{~h}$ significantly reduced delirium and UTI, which is closely consistent with our findings. Considering all these results, we could conclude that the shortened time to surgery might reduce the risk of complication rate by reducing urinary tract

\begin{tabular}{|c|c|c|c|c|c|c|c|c|c|c|c|}
\hline & \multirow{2}{*}{$\begin{array}{l}\text { Study or Subgroup } \\
\text { Haugan } 2017\end{array}$} & \multicolumn{2}{|c|}{ ERAS } & \multicolumn{2}{|c|}{ Control } & \multicolumn{2}{|r|}{$\begin{array}{l}\text { Odds Ratio } \\
\text { M-H. Fixed, } 95 \% \mathrm{Cl}\end{array}$} & \multicolumn{4}{|c|}{$\begin{array}{c}\text { Odds Ratio } \\
\text { M-H. Fixed. } 95 \% \mathrm{Cl}\end{array}$} \\
\hline & & 77 & 1032 & 63 & 788 & $41.4 \%$ & $0.93[0.66,1.31]$ & & $t$ & & \\
\hline & Macfie 2012 & 7 & 117 & 12 & 115 & $7.1 \%$ & $0.55[0.21,1.44]$ & & (十 & & \\
\hline & Pollmann 2019 & 74 & 1140 & 86 & 1090 & $51.5 \%$ & $0.81[0.59,1.12]$ & & - & & \\
\hline & Total $(95 \% \mathrm{Cl})$ & & 2289 & & 1993 & $100.0 \%$ & $0.84[0.67,1.06]$ & & $\gamma$ & & \\
\hline & Total events & 158 & & 161 & & & & & & & \\
\hline & $\begin{array}{l}\text { Heterogeneity: } \mathrm{Chi}^{2}= \\
\text { Test for overall effect: }\end{array}$ & $\begin{array}{l}1.12, d f=2 \\
Z=1.49(P\end{array}$ & $\begin{array}{l}2(P=0 \\
(P=0.14\end{array}$ & $\begin{array}{l}0.57) ; 1^{2}= \\
\text { 4) }\end{array}$ & $=0 \%$ & & & 0.01 & $\begin{array}{cc}0.1 & 1 \\
\text { Favours [ERAS] }\end{array}$ & $\begin{array}{c}10 \\
\text { Favours [control] }\end{array}$ & 100 \\
\hline
\end{tabular}




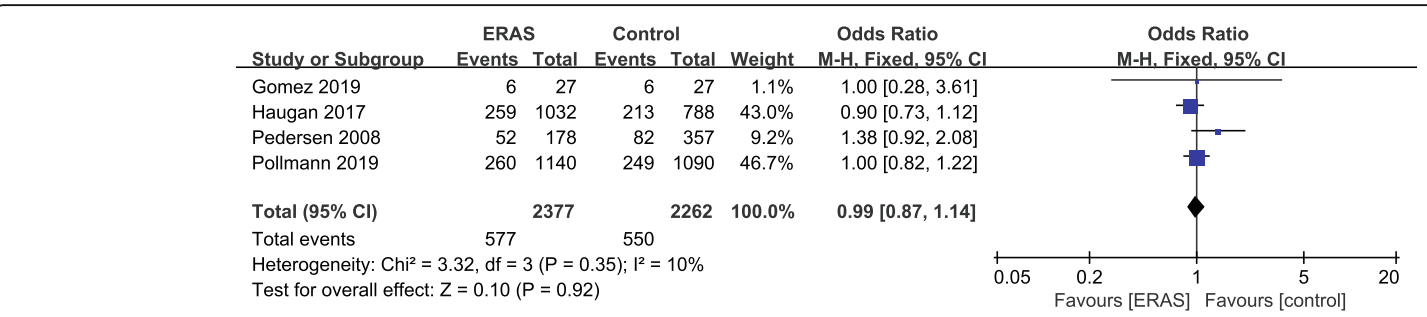

Fig. 7 One-year mortality for ERAS versus the control recovery pathway

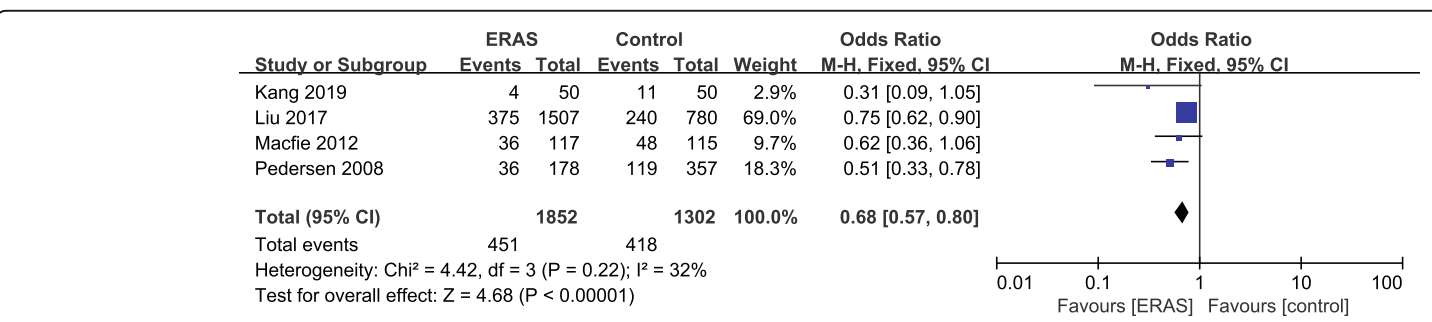

Fig. 8 Overall complication rate for ERAS versus the control recovery pathway

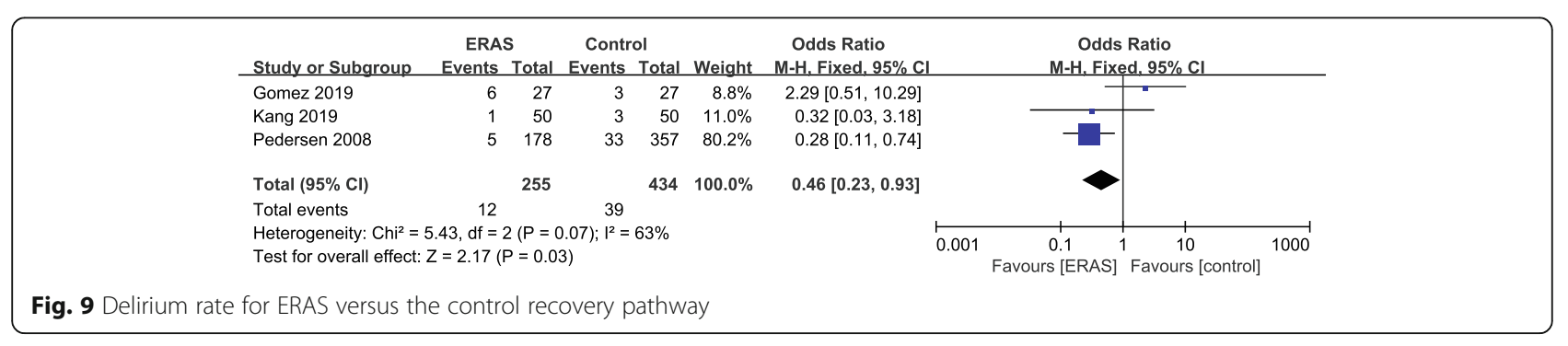

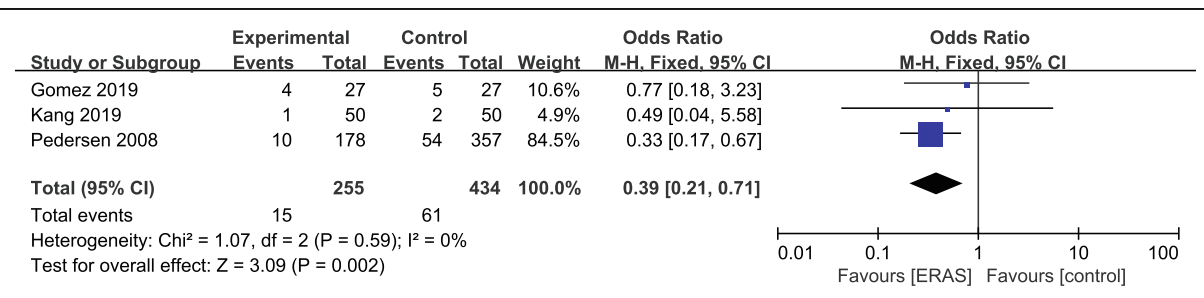

Fig. 10 Urinary tract infection (UTI) rate for ERAS versus the control recovery pathway 


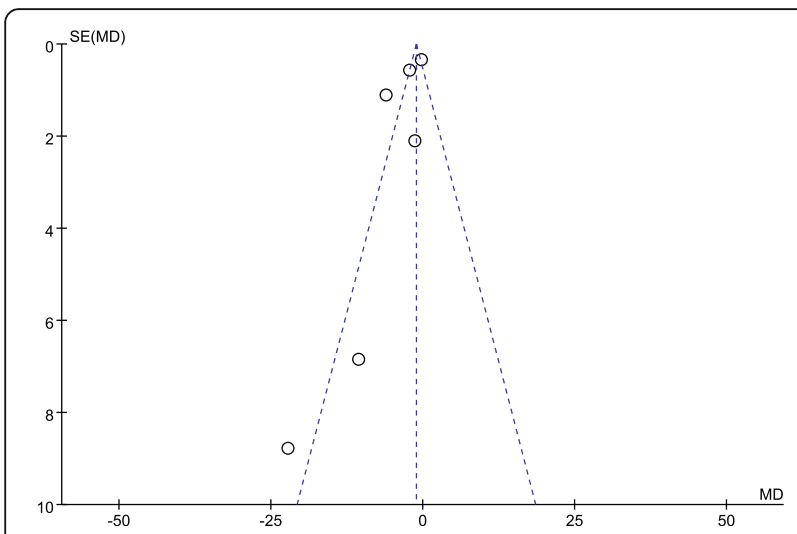

Fig. 11 Funnel plot using TTS as an indicator infection, controlling pain, and getting these patients mobilized earlier than patients assigned to control groups.

\section{Mortality}

Interestingly, despite the shortened time to surgery, reduced LOS, and decreased overall complication rate, no significant change was found in either 30-day mortality or 1-year mortality. It has been reported that the 1-year mortality could reach 30\% after hip fracture (Lund et al. 2014). Numerous factors contribute to mortality after hip fracture. A meta-analysis conducted by Chang et al. identified the time to surgery, residential status, cardiovascular disease, pul-

Table 2 ERAS elements in each article

\begin{tabular}{|c|c|c|c|}
\hline Article & Preoperative & Intraoperative (and surgery) & Postoperative \\
\hline $\begin{array}{l}\text { Pollmann (Pollmann et al. } \\
\text { 2019) }\end{array}$ & $\begin{array}{l}\text { Intravenous fluids } \\
\text { Oxygen } \\
\text { Opiate-sparing pain relief } \\
\text { Electrocardiogram } \\
\text { Triage of hip fractures } \\
\text { X-ray evaluation } \\
\text { Fascia iliaca compartment block } \\
\text { Short periods of fasting }\end{array}$ & $\begin{array}{l}\text { Transfusion triggers } \\
\text { Management of anticoagulants }\end{array}$ & $\begin{array}{l}\text { Pain relief } \\
\text { Standardized mobilization } \\
\text { Screening for nutritional status } \\
\text { Prevention of delirium }\end{array}$ \\
\hline Kang (Kang et al. 2019) & $\begin{array}{l}\text { Preoperative educational program } \\
\text { Oral multimodal analgesia (Celebrex) } \\
\text { Opioid-free spinal anesthesia }\end{array}$ & $\begin{array}{l}\text { Intravenous dexamethasone } \\
2 \mathrm{~L} \text { of lactated Ringer's } \\
\text { Tranexamic acid }\end{array}$ & $\begin{array}{l}\text { Early mobilization } \\
\text { Opioids avoiding } \\
\text { Nausea and vomiting control } \\
\text { Supported discharge }\end{array}$ \\
\hline Gomez (Gomez et al. 2019) & $\begin{array}{l}\text { Geriatrician support } \\
\text { Nursing aids } \\
\text { Physical therapy }\end{array}$ & $\begin{array}{l}\text { General anesthesia with an ultrasound-guided fem- } \\
\text { oral nerve block } \\
\text { No drains } \\
\text { Reduction on traction table }\end{array}$ & $\begin{array}{l}\text { Early food supply } \\
\text { Transfer to postacute rehabilitation (PAR) }\end{array}$ \\
\hline $\begin{array}{l}\text { Haugan et al. (Haugan } \\
\text { et al. 2017) }\end{array}$ & $\begin{array}{l}\text { Oxygen } \\
\text { Standardized } \\
\text { nursing routines (pain control, nutrition, fluid } \\
\text { therapy and } \\
\text { prevention of pressure sores) } \\
\text { Femoral block } \\
\text { Preparation for discharge } \\
\text { Scheduled time for surgery (within } 24 \text { hours) }\end{array}$ & Not mentioned & $\begin{array}{l}\text { Standardized pain control } \\
\text { Standardized mobilization } \\
\text { Medication reconciliation }\end{array}$ \\
\hline Liu (Liu et al. 2017) & $\begin{array}{l}\text { Patient education } \\
\text { No prolonged fasting } \\
\text { Carbohydrate loading } \\
\text { Decreased sedative medications } \\
\text { Regional anesthesia }\end{array}$ & $\begin{array}{l}\text { Antimicrobial prophylaxis } \\
\text { nausea and vomiting prophylaxis } \\
\text { Multimodal analgesia } \\
\text { Standard anesthetic protocol (neuraxial anesthesia } \\
\text { preferred) } \\
\text { Minimally invasive surgery } \\
\text { Avoidance of drains and tubes } \\
\text { Perioperative fluid management } \\
\text { Prevention of hypothermia }\end{array}$ & $\begin{array}{l}\text { Multimodal analgesia } \\
\text { Early oral nutrition } \\
\text { Early and sustained ambulation } \\
\text { Early urinary catheter removal } \\
\text { Deep vein thrombosis prevention } \\
\text { Restoration of gut function Chewing gum } \\
\text { (colorectal) }\end{array}$ \\
\hline $\begin{array}{l}\text { Macfie et al. (Macfie et al. } \\
\text { 2012) }\end{array}$ & $\begin{array}{l}\text { Patient information sheet } \\
\text { Early preassessment } \\
\text { Fascia iliaca block } \\
\text { and optimal analgesia } \\
\text { Limited fasting and carbohydrate loading }\end{array}$ & $\begin{array}{l}\text { High inspired oxygen } \\
\text { Optimal fluid management } \\
\text { Avoidance of drain }\end{array}$ & $\begin{array}{l}\text { Postoperative early mobility Perioperative } \\
\text { nutritional support } \\
\text { Breathing exercise }\end{array}$ \\
\hline Pedersen et al. 2008 & $\begin{array}{l}\text { Specialized hip fracture ward } \\
\text { Pain treatment } \\
\text { Femoral nerve block } \\
\text { Assessment by anesthesiologist } \\
\text { Planning of fluid therapy } \\
\text { Blood sampling } \\
\text { Immediately X-rays evaluation } \\
\text { Oxygen therapy }\end{array}$ & Spinal anesthesia & $\begin{array}{l}\text { Specialized hip fracture ward } \\
\text { Oxygen therapy } \\
\text { Nutrition therapy (protein drinks) } \\
\text { Early mobilization }\end{array}$ \\
\hline
\end{tabular}


monary disease, and malignancy as preventable risk factors significantly associated with mortality (Chang et al. 2018). Toby Smith et al. reported that the four key characteristics associated with the risk of 1-year mortality were abnormal ECG, cognitive impairment, age $>85$ years, and mobility before surgery (Smith et al. 2014). In summary, both the time to surgery and the preoperative characteristics of the patients could affect mortality after hip fracture. This partly explains why in our review, the time to surgery was decreased but the mortality remained unchanged between the ERAS and control groups, as most included studies did not adjust the patients' preoperative status for analysis. In addition, the reduction of $2.96 \mathrm{~h}$ might not reach the cutoff that could exert an effect on mortality. However, an observational study including 4500 patients who underwent hip and knee replacement showed that 2-year mortality was significantly reduced after the introduction of ERAS (Savaridas et al. 2013). The long-term effect of ERAS on hip fracture needs to be further investigated.

\section{Heterogeneity}

The heterogeneity in the outcome of "length of stay" and "time to surgery" was high $\left(I^{2}>75 \%\right)$. We conducted a sensitivity analysis to explore the reason for the high heterogeneity. One study was removed at a time to evaluate the influence of the deleted study on the overall result. However, the heterogeneity remained high regardless of which study was removed. The lack of uniform guidelines leads to diverse means of intervention during the implementation of the ERAS protocol, which might contribute to the high heterogeneity. In addition, the funnel plot was asymmetric, which suggested that there might be publication bias (Fig. 11). Such publication bias might be another reason for the high heterogeneity.

\section{Limitation}

There are several limitations in our review. First, the heterogeneity of some final outcomes was relatively high, as considerable variations in surgical techniques and preoperative patient comorbidities existed among the included studies. Furthermore, the high heterogeneity across the available trials hindered definitive statements, and additional, precisely designed studies are required in this area. Last, no high-quality RCTs met the inclusion criteria, which might cause risks of bias. Thus, the findings in our review should be interpreted cautiously with inherent limitations.

\section{Conclusion}

The results of the meta-analysis showed that the implementation of ERAS can significantly decrease the time to surgery, LOS, and overall complication rate without increasing the 30-day readmission rate and mortality in hip fracture patients. These findings add the value of ERAS to the evidence-based database and indicates that the implementation of a standard ERAS protocol is greatly beneficial to patients with hip fracture. In addition, our results also indicate that future trials should focus on standardized ERAS implementation and its long-term effects on improving the quality and value of surgical care in cases of hip fracture.

\section{Abbreviations}

Cl: Confidence interval; ERAS: Enhanced recovery after surgery; LOS: Length of stay; MD: Mean difference; OR: Odds risks; PRISMA: Preferred Reporting Items for Systematic Reviews and Meta Analyses; RCT: Randomized controlled trial; TTS: Time to surgery; UTI: Urinary tract infection

\section{Acknowledgments}

Not applicable.

\section{Authors' contributions}

SYL was responsible for the concept, design, and drafting of the manuscript. $S Y L$ and $C L$ contributed to the literature search, trial selection, and data collection. SYL, CL and PXZ contributed to the analysis and interpretation of the data. PXZ provided consultation for statistics and methodology. PXZ critically revised the article. All authors read and approved the final manuscript.

\section{Funding}

The study was funded by 1) the Key Laboratory of Trauma and Neural Regeneration (Peking University), Ministry of Education, 2) a grant from National Center for Trauma Medicine (BMU2020XY005-01), 3) Capital

Foundation of Medicine Research and Development (2018-4-7011) and

(4) the National Natural Science Foundation $(31771322,31571235,81971177)$.

\section{Availability of data and materials}

All data generated or analyzed during this study are included in this published article and its supplementary information files.

\section{Declarations}

Ethics approval and consent to participate

Ethical approval was not sought, as we extracted data from already published work.

Consent for publication

Not applicable.

Competing interests

The authors declare that they have no competing interests.

Received: 12 September 2020 Accepted: 22 June 2021

Published online: 13 September 2021

\footnotetext{
References

Al-Ani AN, Samuelsson B, Tidermark J, et al. Early operation on patients with a hip fracture improved the ability to return to independent living. A prospective study of 850 patients. J Bone Joint Surg Am. 2008;90(7):1436-42. https://doi.org/10.2106/JBJS.G.00890.

Basques BABB, Daniel D, Golinvaux NS, Leslie MP, Baumgaertner MR, Grauer JN. Postoperative length of stay and 30-day readmission after geriatric hip fracture. J Orthopaedic Trauma. 2015;29(3):e115-20. https://doi.org/10.1097/ BOT.00000000000000222.

Beloosesky Y, Hendel D, Weiss A, Hershkovitz A, Grinblat J, Pirotsky A, et al. Cytokines and C-reactive protein production in hip-fracture-operated elderly patients. J Gerontol A Biol Sci Med Sci. 2007;62(4):420-6. https://doi.org/10.1 093/gerona/62.4.420.
} 
Bozic KJ, Maselli J, Pekow PS, Lindenauer PK, Vail TP, Auerbach AD. The influence of procedure volumes and standardization of care on quality and efficiency in total joint replacement surgery. J Bone Joint Surg Am. 2010;92(16):264352. https://doi.org/10.2106/JBJS.I.01477.

Bretherton CP, Parker MJ. Early surgery for patients with a fracture of the hip decreases 30-day mortality. Bone Joint J. 2015;97-B(1):104-8. https://doi.org/1 0.1302/0301-620X.97B1.35041

Brox WT, Roberts KC, Taksali S, Wright DG, Wixted JJ, Tubb CC, et al. The American Academy of Orthopaedic Surgeons Evidence-Based Guideline on Management of Hip Fractures in the Elderly. J Bone Joint Surg Am. 2015; 97(14):1196-9. https://doi.org/10.2106/JBJS.0.00229.

Capelastegui A, Espana PP, Quintana JM, et al. Declining length of hospital stay for pneumonia and postdischarge outcomes. Am J Med. 2008;121(10):84552. https://doi.org/10.1016/j.amjmed.2008.05.010.

Chang W, Lv H, Feng C, Yuwen P, Wei N, Chen W, et al. Preventable risk factors of mortality after hip fracture surgery: Systematic review and meta-analysis. Int J Surg. 2018;52:320-8. https://doi.org/10.1016/j.jjsu.2018.02.061.

Chen $\mathrm{Hu} J$, Xin Jiang $L$, Cai L, et al. Preliminary experience of fast-track surgery combined with laparoscopy-assisted radical distal gastrectomy for gastric cancer. J Gastrointest Surg. 2012;16(10):1830-9. https://doi.org/10.1007/s11 605-012-1969-4.

Chuang D, Power SE, Dunbar PR, Hill AG. Central nervous system interleukin-8 production following neck of femur fracture. ANZ J Surg. 2005;75(9):813-6. https://doi.org/10.1111/j.1445-2197.2005.03530.x.

Coolsen MM, van Dam RM, van der Wilt AA, et al. Systematic review and metaanalysis of enhanced recovery after pancreatic surgery with particular emphasis on pancreaticoduodenectomies. World J Surg. 2013;37(8):1909-18. https://doi.org/10.1007/s00268-013-2044-3.

Desborough JP. The stress response to trauma and surgery. Br J Anaesthesia. 2000;85(1):109-17. https://doi.org/10.1093/bja/85.1.109.

French DD, Bass E, Bradham DD, Campbell RR, Rubenstein ALZ. Rehospitalization after hip fracture: predictors and prognosis from a national veterans study. J Am Geriatr Soc. 2008;56(4):705-10. https://doi.org/10.1111/j.1532-5415.2007.01479.x.

Gomez M, Marc C, Talha A, Ruiz N, Noublanche S, Gillibert A, et al. Fast track care for pertrochanteric hip fractures: how does it impact length of stay and complications? Orthop Traumatol Surg Res. 2019;105(5):979-84. https://doi. org/10.1016/j.otsr.2019.04.017.

Greco M, Capretti G, Beretta L, Gemma M, Pecorelli N, Braga M. Enhanced recovery program in colorectal surgery: a meta-analysis of randomized controlled trials. World J Surg. 2014;38(6):1531-41. https://doi.org/10.1007/ s00268-013-2416-8.

Haugan K, Johnsen LG, Basso T, Foss OA. Mortality and readmission following hip fracture surgery: a retrospective study comparing conventional and fast-track care. BMJ Open. 2017;7(8):e015574. https://doi.org/10.1136/bmjopen-2016-015574.

Higgins JP, Thompson SG, Deeks JJ, Altman DG. Measuring inconsistency in meta-analyses. BMJ. 2003;327(7414):557-60. https://doi.org/10.1136/bmj.327. 7414.557.

Investigators HA. Accelerated surgery versus standard care in hip fracture (HIP ATTACK): an international, randomised, controlled trial. Lancet. 2020; 395(10225):698-708.

Ireland AW, Kelly PJ, Cumming RG. Total hospital stay for hip fracture: measuring the variations due to pre-fracture residence, rehabilitation, complications and comorbidities. BMC Health Serv Res. 2015;15(1):17. https://doi.org/10.1186/s12 913-015-0697-3

Jencks SF, Williams MV, Coleman EA. Rehospitalizations among patients in the Medicare fee-for-service program. N Engl J Med. 2009;360(14):1418-28. https://doi.org/10.1056/NEJMsa0803563.

Kang Y, Liu J, Chen H, Ding W, Chen J, Zhao B, et al. Enhanced recovery after surgery (ERAS) in elective intertrochanteric fracture patients result in reduced length of hospital stay (LOS) without compromising functional outcome. J Orthop Surg Res. 2019;14(1):209. https://doi.org/10.1186/s13018-019-1238-2.

Kaoutzanis C, Ganesh Kumar N, O'Neill D, et al. Enhanced recovery pathway in microvascular autologous tissue-based breast reconstruction: should it become the standard of care? Plast Reconstr Surg. 2018;141(4):841-51. https://doi.org/10.1097/PRS.0000000000004197.

Kates SL, Behrend C, Mendelson DA, Cram P, Friedman SM. Hospital readmission after hip fracture. Arch Orthop Trauma Surg. 2015a;135(3):329-37. https://doi. org/10.1007/s00402-014-2141-2.

Kates SL, Shields E, Behrend C, Noyes KK. Financial implications of hospital readmission after hip fracture. Geriatr Orthop Surg Rehabil. 2015b;6(3):140-6. https://doi.org/10.1177/2151458515578265.
Kehlet H. Multimodal approach to control postoperative pathophysiology and rehabilitation. Br J Anaesthesia. 1997;78(5):606-17. https://doi.org/10.1093/ bja/78.5.606.

Khan MA, Hossain FS, Dashti Z, et al. Causes and predictors of early re-admission after surgery for a fracture of the hip. J Bone Joint Surg Br. 2012;94(5):690-7.

Klop C, Welsing PM, Cooper C, et al. Mortality in British hip fracture patients, 2000-2010: a population-based retrospective cohort study. Bone. 2014;66: 171-7. https://doi.org/10.1016/j.bone.2014.06.011.

Larsen K, Sorensen OG, Hansen TB, et al. Accelerated perioperative care and rehabilitation intervention for hip and knee replacement is effective: a randomized clinical trial involving 87 patients with 3 months of follow-up. Acta Orthop. 2008;79(2):149-59. https://doi.org/10.1080/17453670710014923.

Leigheb F, Vanhaecht K, Sermeus W, Lodewijckx C, Deneckere S, Boonen S, et al. The effect of care pathways for hip fractures: a systematic overview of secondary studies. Eur J Orthop Surg Traumatol. 2013;23(7):737-45. https:// doi.org/10.1007/s00590-012-1085-X.

Liu VX, Rosas E, Hwang J, Cain E, Foss-Durant A, Clopp M, et al. Enhanced recovery after surgery program implementation in 2 surgical populations in an integrated health care delivery system. JAMA Surg. 2017;152(7):e171032. https://doi.org/10.1001/jamasurg.2017.1032.

Ljungqvist O, Scott M, Fearon KC. Enhanced recovery after surgery: a review. JAMA Surg. 2017;152(3):292-8. https://doi.org/10.1001/jamasurg.2016.4952.

Lund CA, Moller AM, Wetterslev J, et al. Organizational factors and long-term mortality after hip fracture surgery. A cohort study of 6143 consecutive patients undergoing hip fracture surgery. PLoS One. 2014;9(6):e99308.

Macfie D, Zadeh RA, Andrews M, Crowson J, Macfie J. Perioperative multimodal optimisation in patients undergoing surgery for fractured neck of femur. Surgeon. 2012;10(2):90-4. https://doi.org/10.1016/j.surge.2011.01.006.

Moher D, Liberati A, Tetzlaff J, Altman DG, for the PRISMA Group. Preferred reporting items for systematic reviews and meta-analyses: the PRISMA statement. BMJ. 2009;339(jul21 1):b2535. https://doi.org/10.1136/bmj.b2535.

Mosk CA, Mus M, Vroemen JP, van der Ploeg T, Vos D, Elmans L, et al. Dementia and delirium, the outcomes in elderly hip fracture patients. Clin Interv Aging. 2017;12:421-30. https://doi.org/10.2147/CIA.S115945.

Mundi S, Pindiprolu B, Simunovic N, Bhandari M. Similar mortality rates in hip fracture patients over the past 31 years. Acta Orthop. 2014;85(1):54-9. https:// doi.org/10.3109/17453674.2013.878831.

Ni TG, Yang HT, Zhang H, Meng HP, Li B. Enhanced recovery after surgery programs in patients undergoing hepatectomy: A meta-analysis. World J Gastroenterol. 2015;21(30):9209-16. https://doi.org/10.3748/wjg.v21.i30.9209.

Nikkel LE, Kates SL, Schreck M, et al. Length of hospital stay after hip fracture and risk of early mortality after discharge in New York state: retrospective cohort study. BMJ. 2015;351:h6246.

Nordstrom P, Gustafson Y, Michaelsson K, Nordstrom A. Length of hospital stay after hip fracture and short term risk of death after discharge: a total cohort study in Sweden. BMJ. 2015;350(feb20 1):h696. https://doi.org/10.1136/bmj. h696.

Nyholm AM, Gromov K, Palm H, Brix M, Kallemose T, Troelsen A, et al. Time to surgery is associated with thirty-day and ninety-day mortality after proximal femoral fracture: a retrospective observational study on prospectively collected data from the Danish Fracture Database collaborators. J Bone Joint Surg Am. 2015;97(16):1333-9. https://doi.org/10.2106/JBJS.0.00029.

Pedersen SJ, Borgbjerg FM, Schousboe B, Pedersen BD, JÃ, rgensen HL, Duus BR, et al. A comprehensive hip fracture program reduces complication rates and mortality. J Am Geriatr Soc. 2008;56(10):1831-8. https://doi.org/10.1111/j.1 532-5415.2008.01945.x.

Petersen MB, Jorgensen $\mathrm{HL}$, Hansen $\mathrm{K}$, et al. Factors affecting postoperative mortality of patients with displaced femoral neck fracture. Injury. 2006;37(8): 705-11. https://doi.org/10.1016/j.injury.2006.02.046.

Pincus D, Ravi B, Wasserstein D, Huang A, Paterson JM, Nathens AB, et al. Association Between Wait Time and 30-Day Mortality in Adults Undergoing Hip Fracture Surgery. JAMA. 2017;318(20):1994-2003. https://doi.org/10.1001/ jama.2017.17606.

Pollmann $C T$, Rotterud JH, Gjertsen JE, et al. Fast track hip fracture care and mortality - an observational study of 2230 patients. BMC Musculoskelet Disord. 2019;20(1):248. https://doi.org/10.1186/s12891-019-2637-6.

Savaridas T, Serrano-Pedraza I, Khan SK, Martin K, Malviya A, Reed MR. Reduced medium-term mortality following primary total hip and knee arthroplasty with an enhanced recovery program. A study of 4,500 consecutive procedures. Acta Orthop. 2013;84(1):40-3. https://doi.org/10.3109/17453674.2 013.771298. 
Sheikh HQ, Hossain FS, Aqil A, Akinbamijo B, Mushtaq V, Kapoor H. A comprehensive analysis of the causes and predictors of 30-day mortality following hip fracture surgery. Clin Orthop Surg. 2017;9(1):10-8. https://doi. org/10.4055/cios.2017.9.1.10

Simunovic N, Devereaux PJ, Sprague S, Guyatt GH, Schemitsch E, DeBeer J, et al. Effect of early surgery after hip fracture on mortality and complications: systematic review and meta-analysis. CMAJ. 2010;182(15):1609-16. https://doi. org/10.1503/cmai.092220.

Smith T, Pelpola K, Ball M, Ong A, Myint PK. Pre-operative indicators for mortality following hip fracture surgery: a systematic review and meta-analysis. Age and ageing. 2014;43(4):464-71. https://doi.org/10.1093/ageing/afu065.

Stang A. Critical evaluation of the Newcastle-Ottawa scale for the assessment of the quality of nonrandomized studies in meta-analyses. Eur J Epidemiol. 2010;25(9):603-5. https://doi.org/10.1007/s10654-010-9491-z.

Sund $\mathrm{R}$, Juntunen $\mathrm{M}$, Luthje $\mathrm{P}$, et al. Monitoring the performance of hip fracture treatment in Finland. Ann Med. 2011;43(Suppl 1):S39-46. https://doi.org/10.31 09/07853890.2011.586360.

Varadhan KK, Neal KR, Dejong CH, et al. The enhanced recovery after surgery (ERAS) pathway for patients undergoing major elective open colorectal surgery: a meta-analysis of randomized controlled trials. Clin Nutr. 2010;29(4): 434-40. https://doi.org/10.1016/j.clnu.2010.01.004.

Visioni A, Shah R, Gabriel E, Attwood K, Kukar M, Nurkin S. Enhanced recovery after surgery for noncolorectal surgery?: a systematic review and metaanalysis of major abdominal surgery. Ann Surg. 2018;267(1):57-65. https://doi. org/10.1097/SLA.0000000000002267.

Westberg M, Snorrason F, Frihagen F. Preoperative waiting time increased the risk of periprosthetic infection in patients with femoral neck fracture. Acta Orthop. 2013;84(2):124-9. https://doi.org/10.3109/17453674.2013.775044.

Zhu S, Qian W, Jiang C, Ye C, Chen X. Enhanced recovery after surgery for hip and knee arthroplasty: a systematic review and meta-analysis. Postgrad Med J. 2017;93(1106):736-42. https://doi.org/10.1136/postgradmedj-2017-134991.

\section{Publisher's Note}

Springer Nature remains neutral with regard to jurisdictional claims in published maps and institutional affiliations.

Ready to submit your research? Choose BMC and benefit from:

- fast, convenient online submission

- thorough peer review by experienced researchers in your field

- rapid publication on acceptance

- support for research data, including large and complex data types

- gold Open Access which fosters wider collaboration and increased citations

- maximum visibility for your research: over $100 \mathrm{M}$ website views per year

At $\mathrm{BMC}$, research is always in progress.

Learn more biomedcentral.com/submissions 